\title{
Complementary roles of two resilient neotropical mammalian seed dispersers
}

\author{
Adriana de Almeida ${ }^{\mathrm{a}, \mathrm{b}, \mathrm{c}}$, Rebecca J. Morris ${ }^{\mathrm{b}, \mathrm{d}}$, Owen T. Lewis ${ }^{\mathrm{b}}$, Sandra B. Mikich ${ }^{\mathrm{b}, \mathrm{c}, *}$ \\ a Curso de Pós-Graduação em Biologia Animal, Instituto de Biociências, Letras e Ciências Exatas, Universidade Estadual Paulista Júlio de Mesquita Filho, Rua Cristóvão \\ Colombo 2265, 15054-000, São José do Rio Preto, São Paulo, Brazil \\ ${ }^{\mathrm{b}}$ Department of Zoology, The Tinbergen Building, South Parks Road, University of Oxford, OX1 3PS, Oxford, United Kingdom \\ ${ }^{\mathrm{c}}$ Embrapa Florestas, Estrada da Ribeira Km 111, CP: 319, 83411-000, Colombo, Paraná, Brazil \\ d Biological Sciences, Faculty of Natural and Environmental Sciences, Life Sciences Building 85, University of Southampton, Highfield Campus, Southampton, SO17 1BJ, \\ UK
}

\section{A R T I C L E I N F O}

\section{Keywords:}

Cebus

Ecological networks

Frugivory

Nasua

Sapajus

Seed dispersal

\begin{abstract}
A B S T R A C T
Capuchin monkeys (Cebus spp. and Sapajus spp.) and coatis (Nasua spp.) coexist in most neotropical forests, including small forest remnants. Both capuchins and coatis eat fruit and disperse seeds, but little is known about whether their roles in seed dispersal are redundant or complementary. We compiled 49 studies from the literature on feeding by capuchins and/or coatis, of which 19 were comprehensive enough for our analyses. We determined the relative importance of fruit eating to each species and compared their diets. Additionally, we analysed the structure of three fruit-frugivore networks built with both animal groups and the fruits they eat and evaluated whether fruit traits influenced the network topology. Fruits represented the largest part of capuchin and coati diets, even though coatis have been known for their opportunistic and generalist diets. Capuchins and coatis also exhibited similar general diet parameters (niche breadth and trophic diversity). The three networks exhibited high connectance values and variable niche overlap. A Multiple Correspondence Analysis, failed to detect any trait or trait combination related to food use. In conclusion, capuchins and coatis both have generalist diets; they feed on many different species of fruits and exhibit important complementarity as seed dispersers. Both are likely to be particularly important seed dispersers in disturbed and fragmented forests.
\end{abstract}

\section{Introduction}

Plant-animal interactions are among the main processes that generate and maintain biodiversity (Odum and Barrett, 2008). In the tropics, mutualisms such as pollination and seed dispersal play a central role, with up to $90 \%$ of plant species dependent on animals for their reproduction (Howe and Smallwood, 1982; Jordano, 2000). Many plant species produce fruits with edible parts which attract frugivorous animals (Howe and Smallwood, 1982). These animals benefit from the interaction because the fruits act as an energy source, while the plants have their seeds carried away from parent plants, increasing their probability of recruitment (Howe and Miriti, 2004; Janzen, 1971). Seed dispersal by frugivores is a key process in plant population dynamics (Terborgh, 1995), and in highly fragmented landscapes it can increase the chances of restoration of degraded lands (Duncan and Chapman, 2002) and gene flow among natural vegetation patches (Jordano and Godoy, 2002).
However, medium and large-sized frugivores are becoming extinct or have extremely reduced populations in many tropical ecosystems (Wright et al., 2007), mainly as a result of hunting and habitat loss (Chiarello, 1999; Cullen et al., 2000; Peres and Palacios, 2007). This can impact ecosystem structure and dynamics due to the disruption of key interactions, including those related to seed dispersal (Donatti et al., 2011; Galetti et al., 2013; Galetti and Dirzo, 2013; Peres and van Roosmalen, 2002). In this scenario, some resilient seed dispersing species may become very important because they can provide continuity to essential processes in the forest (Alves-Costa and Eterovick, 2007).

Capuchin monkeys (Primates: Cebidae, genera Cebus Erxleben and Sapajus Kerr) and coatis (Carnivora: Procyonidae, genus Nasua Storr) are among the medium-bodied frugivores that can persist in small Neotropical forest fragments (Chiarello, 1999). These two mammal groups are omnivores, but fruits can comprise a major part of their diets, reaching up to 89\% for capuchins (Galetti and Pedroni, 1994;

\footnotetext{
* Corresponding author. Embrapa Florestas, Estrada da Ribeira Km 111, CP: 319, 83411-000, Colombo, Paraná, Brazil.

E-mail addresses: adri_dealmeida@hotmail.com (A. de Almeida), rebecca.morris@zoo.ox.ac.uk (R.J. Morris), owen.lewis@zoo.ox.ac.uk (O.T. Lewis), sandra.mikich@embrapa.br (S.B. Mikich).
} 
Janson, 1985; Mikich, 2001; Moscow and Vaughan, 1987; Rocha, 2001), and 72\% for coatis (Aguiar et al., 2011; Gompper, 1996; Mikich, 2001; Russell, 1983).

Capuchin monkeys are arboreal and social primates (Freese and Oppenheimer, 1981), which are widely distributed throughout the Neotropics. Species of the genus Cebus are found in the Amazon and Central America, while species of the genus Sapajus are distributed through South America, occupying a variety of habitat types, from dense rainforests and wetlands to areas of Cerrado and Caatinga (Freese and Oppenheimer, 1981; IUCN, 2013).

Coatis are scansorial (they can travel and forage on the ground but are also adapted for climbing trees, where they can forage, avoid predators, sleep and breed), social mammals, although adult males are solitary (Gompper, 1995; Gompper and Decker, 1998). The two extant species have non-overlapping distributions: Nasua narica (Linnaeus, 1766) in Central America and southern North America, and Nasua nasua (Linnaeus, 1766) in South America, from Colombia and Venezuela to Uruguay and Argentina (IUCN, 2016).

Capuchin monkeys and coatis are relatively common to abundant in Neotropical forests (Eisenberg and Thorington, 1973; Gompper and Decker, 1998), and their geographical ranges overlap. Given their potential importance as frugivores in highly disturbed habitats, where large-seeded plant species may depend on only a few frugivorous species for seed dispersal (Alves-Costa and Eterovick, 2007; Vidal et al., 2013), information on their diets and interactions is valuable to inform forest conservation and restoration programmes. Due to their diets, habits and behaviour, it is expected that these two mammal groups will exhibit both similarities and dissimilarities regarding their ecological functions and interactions, even in shared habitats, which may affect the wider ecological community.

The mutualisms between animals and plants form a complex network of interactions (Bascompte and Jordano, 2007) affecting the structure and stability of a community (Maruyama et al., 2014; Vázquez et al., 2009). Plant ecological traits can shape the interactions between plants and animal visitors, constraining the number and identity of interacting species (Jordano et al., 2003), and therefore affecting the patterns of interactions or the network structures, both for plant-pollinator (Junker et al., 2013; Maglianesi et al., 2014; Maruyama et al., 2014; Schleuning et al., 2015; Vizentin-Bugoni et al., 2014) and frugivory and seed dispersal networks (Dehling et al., 2014; GonzalezCastro et al., 2015). Trait-based analyses have proven the importance of traits of interacting species for the dynamics of interactions, for example morphological matches between plants and their pollinators in pollination networks (Junker et al., 2013; Maglianesi et al., 2014). Morphological matches have also been shown to be important in determining community structure, as well as species abundances, for plant and avian-seed dispersal interactions (Gonzalez-Castro et al., 2015). However, studies incorporating the influence of species' traits in structuring ecological networks are still scarce (Kissling and Schleuning, 2015), particularly for plant-seed dispersal systems. Furthermore, little is known about the role of species' traits in structuring networks involving frugivore groups other than birds.

Thus, in this paper, our objectives were: (1) to determine the importance of fruits in the diets of capuchins and coatis, and the consistency of the diets of both groups across their geographical distribution; (2) to compare diet parameters between these two mammalian groups, and to investigate the possible causes of any differences; and (3) to identify key plant traits linked to these groups' fruit preferences. We predicted that fruits should represent a lower fraction of coatis' diets compared to capuchins', considering their different life histories, foraging habits and general behaviour. Due to morphological and behavioural differences between the two groups, we expected diet breadth and diversity to differ, with capuchins favouring fruit consumption over other items, and as a result exploiting a higher fruit species diversity than coatis. We also expected plant, fruit and/or seed traits to explain the trophic interaction structure for these two taxa. It is known that morphological traits of fruits, such as colour, fruit and seed sizes, and type of fruit, can be associated with character syndromes associated with different taxa (Gautier-Hion et al., 1985). Primates tend to favour bright or multicoloured and arillate fruit species while other mammals are particularly more attracted to dull-coloured, large, and fibrous fruit species (Gautier-Hion et al., 1985).

To test our predictions, we gathered data from a systematic literature review to evaluate frugivory by capuchin monkeys and coatis and their interactions with fruit plants over the Neotropical region. Additionally, for three case studies where detailed data were available on capuchin and coati feeding associations, we investigated fruit-frugivore network structure in order to evaluate the influence of fruit/ plant traits on the use of these resources by capuchin monkeys and coatis.

\section{Methods}

\subsection{Data compilation}

We performed a broad review, using the Web of Science database (http://apps.webofknowledge.com), our own knowledge of the literature, dissertations, theses, and our own unpublished data about the diets of wild populations of capuchin monkeys and coatis. For capuchins, the search in the database was performed using the keywords [(“Cebus" OR "Sapajus") AND "diet"], and all studies listed until August 2016 were analysed. For coatis, the investigation included all studies published until August 2016 that resulted from the search of the term "Nasua". We did not use the "diet" filter in this last search because there were already few results and we did not want to miss any relevant studies. In order to compare the diet parameters (trophic diversity and niche breadth) between the two mammalian groups, we selected diet studies that described all recognisable food items, and not just the dominant foods, conducted during $\geq 12$ months, and where the relative frequencies of occurrence of the different items in their diet (e.g. fruit + seeds, non-fruit plant parts and animal matter) were reported or could be calculated. We used studies where the method could quantify the frequency of occurrence of different items as this tends to include even rare and important food sources (Robinson, 1986). We used original datasets whenever available, and secondary data when the original data were not accessible.

The taxonomy of both capuchins and plants can be controversial. For the capuchins, we followed the proposal of Alfaro et al. (2012a, 2012b). For plants, scientific names and classifications were verified according to The Plant List database (http://www.theplantlist.org).

\subsection{Case studies}

Despite a reasonable number of studies published on the diets and/ or seed dispersal of both groups (35 studies for capuchin monkeys and 16 studies for coatis) and the considerable overlap in their geographical ranges, only two study sites had the diets of both groups investigated at the same time and with the same methodology (Mikich, 2001; Rocha, 2001). Additionally, one study site (Barro Colorado Island, Panama) had a number of independent, detailed and consistent observational studies on the diets of capuchins and coatis (Oppenheimer, 1968 apud Freese and Oppenheimer, 1981; Hladik and Hladik, 1969; Kaufmann, 1962; Russell, 1983), making it possible to combine data from different sources for some analyses.

Our network analyses therefore focused on these three case studies, where each study had the same sampling effort for capuchins and coatis within the study-although sampling effort was not consistent across studies-which we now describe in detail.

The first study system included data on Sapajus nigritus (Goldfuss, 1809) and N. nasua interacting with 101 plant species (S. B. Mikich, in prep.). This author collected the data in a protected area called Vila Rica do Espírito Santo State Park, which is located in the interior 
portion of the Atlantic forest of Parana state, southern Brazil, munici-

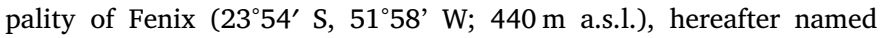
Fenix. The climate is subtropical (Cfa, according to the Köppen-Geiger classification; Kottek et al., 2006) with mean temperatures below $18^{\circ} \mathrm{C}$ during winter and above $22^{\circ} \mathrm{C}$ during summer; annual rainfall between 1400 and $1500 \mathrm{~mm}$ with twice as much rain in the summer than in the winter. The vegetation type is semi-deciduous seasonal forest in the form of a 354-ha fragment of old secondary forest (almost 400 years old and similar to primary forests according to Mikich and Silva, 2001) surrounded by an agricultural matrix. Although this fragment is protected, poaching occurs (Rocha-Mendes et al., 2005), but the main threats to wildlife are the hunting by domestic dogs, and the reduced size and isolation of the fragment (Mikich and Oliveira, 2003). Due to the scarcity of top predators and the abundance of food, the population of both capuchins and coatis have increased considerably (Mikich and Oliveira, 2003; Rocha-Mendes et al., 2005) so they are now among the most abundant mammal species within this protected area. The sampling methods were both direct observation ad libitum and faecal samples collected monthly between May 1990 and December 1999 along a trail system ( $9 \mathrm{~km}$ long) (Mikich, 2001). Each visual encounter with one feeding individual or group was taken as a feeding record, as was each item or plant species found in the faecal samples, making the visual and faecal data points equivalent in this case, totalling 5808 feeding records by capuchin monkeys and 729 by coatis.

The second study system had the same monkey and coati species found in Fenix, interacting with 50 plant species (Rocha, 2001). It is a 680-ha protected area also located in Parana state, municipality of

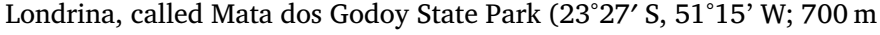
a.s.l.), hereafter named Godoy. The climate, vegetation type and surrounding matrix are all similar to Fenix. Godoy is a relatively wellpreserved area and it is connected to neighbouring forest fragments with different levels of disturbances, totalling approximately 1800 ha of forests (Rocha, 2001). According to Rocha (2001), capuchin monkeys and coatis are among the most commonly observed mammals in the area, which may be related to a low number of top predators. The author conducted monthly samplings between October 1993 and September 1994 and between April 1996 and March 1998. Data collection and counting of feeding records were the same employed in Fenix and totalled 241 feeding records by capuchin monkeys and 134 by coatis (Rocha, 2001).

The third study system is based on data presented in four different studies conducted in Barro Colorado Island, Panama $\left(9^{\circ} 09^{\prime} \mathrm{N}, 79^{\circ} 51^{\prime} \mathrm{W}\right.$; $25 \mathrm{~m}$ a.s.l.), merged as a single dataset, hereafter named BCI. Barro Colorado is a 1560-ha island formed following the construction of the Panama Canal, between 1911 and 1914, when the River Chagres was dammed (Croat, 1978). The climate is equatorial monsoon climate (Am, according to the Köppen-Geiger classification; Kottek et al., 2006), annual rainfall ranges from 190 to $360 \mathrm{~mm}$. The vegetation type is semievergreen moist tropical forest (Croat, 1978). The island is composed of late secondary forest (Knight, 1975) and poaching is under control. Cebus capucinus (Linnaeus, 1758) and $N$. narica are among the most abundant mid-sized fruit-eating mammals in the area (Wright et al., 1994). The first study was conducted by Kaufmann (1962) on $N$. narica between July 1958 and June 1960, when the author followed five groups of coatis during a total of $1370 \mathrm{~h}$ recording 19 consumed plant species through direct observation. The second study, conducted by Oppenheimer (1968 apud Freese and Oppenheimer, 1981) between March 1966 and August 1967, recorded 66 plant species in the diet of C. capucinus through direct observation. The third study, also on the diet of C. capucinus, was performed between November 1966 and January 1968 by Hladik and Hladik (1969). They followed the monkeys and recorded the consumption of 45 plant species also through direct observation. The last study was conducted by Russell (1983), who recorded feeding bouts in 24 fruit species by two habituated groups of $N$. narica during 14 months (between August and September 1975, June and October 1977 and January and July 1978). The combined dataset totalled 108 distinct plant species. Inevitably that there are some methodological limitations in combining these data into a single $\mathrm{BCI}$ network. Although the different studies were all sampled using direct observation by following habituated bands during long periods, they involved different sampling efforts, were conducted by different investigators, were not concurrent and had different durations. Study duration will also influence the size of the network and the plant species recorded and therefore this needs to be taken into consideration. Although the data were collected over an extended period, there was little change in the plant species recorded, or in the extent of forest on BCI. We therefore we decided that combining the data sets was appropriate for our purposes.

\subsection{Plant traits}

Using plant identities would make it difficult to perform further comparisons among the three case studies since there is little overlap in plant species, especially with BCI, due to geographical and climatic differences between the sites. Therefore, we instead used plant traits known to be important for frugivores, aiming to find key traits that might have been favoured by each mammal in the study sites. Plant life form, fruit type, fruit colour, fruit size, seed size, number of seeds per fruit were compiled for the 293 plant species found in the studies based on published data (Croat, 1978; Jordano, 1995; Mikich and Silva, 2001; Wright et al., 2010). To perform the analyses, these traits were standardized as follows: five categories of plant life forms (climber; epiphyte; herb; shrub; and tree), seven categories of fruit types (aril; berry; drupe; fleshy aggregates; grain; pod; and samara), eight categories of fruit colours (black; brown; blue + purple; green; orange; red + burgundy; white; yellow), five categories of number of seeds per fruit (one $=1$ seed; two $=2$ seeds; three $=3$ to 4 seeds; four $=5$ to 10 seeds; and five $=>10$ seeds), and five intervals of fruit sizes (one $=[0,6] \mathrm{mm}$; two $=] 6,10] \mathrm{mm}$; three $=] 10,20] \mathrm{mm}$; four $=]$ $20,50] \mathrm{mm}$; and five $=] 50, \infty[\mathrm{mm}$ ) and seed sizes (one $=[0,3] \mathrm{mm}$; two $=] 3,6] \mathrm{mm}$; three $=] 6,10] \mathrm{mm}$; four $=] 10,20] \mathrm{mm}$; and five $=] 20, \infty[\mathrm{mm})$.

\subsection{Data analyses}

To compare patterns in the composition and diversity of capuchin and coati diets, we calculated trophic diversity (Shannon's diversity index, $H^{\prime}$ ) and niche breadth (Levin's index, $B$ ) based on the relative percentage of occurrence of the main food categories (fruits and seeds, non-fruit plant parts, and animal matter) in their diets (see Zhou et al., 2011). These indexes were obtained for each study containing information on the proportion of different food items consumed. To assess differences in trophic diversity and niche breadth between capuchin and coati diets, we used $t$-tests.

Food web analyses were performed to describe the topology of the three case study communities with data on fruit consumption by both capuchins and coatis. Thus, these were sub-networks of the lager (unstudied) plant-frugivore networks at each site, restricted to the two focal frugivores and the fruit species they eat. These networks had only presence-absence data, allowing us to determine some qualitative characteristics. We used six metrics to describe the structure of the three networks: network size $(S)$, connectance or connectivity $(C)$, mean number of links per species $\left(\overline{L_{\mathrm{x}}}\right)$, niche overlap $(N O)$, modularity $(M)$, and mean normalised degree of the species on the higher trophic level $(N D) . N O$ indicates the mean similarity in the pattern of interactions between species of the same trophic level. We calculated the NO between the species in the higher trophic level, in this case capuchins and coatis. It was determined by the Horn index (Dormann et al., 2009), and can vary from 0 (no niche overlap) to 1 (total niche overlap). Modularity is characterized by groups of species that are highly connected between them that have only a few connections with other species belonging to other groups in the network (Olesen et al., 2007). To 
calculate it we used Barber modularity index, $M_{\mathrm{B}}$ (Barber, 2007), which determines how many interactions a species has within its module, relative to those expected at random. $N D$ is a measure of generalisation defined as the proportion of species a particular species interacts with, out of the total possible in the network (Martín González et al., 2010). Statistical significances of the indices $C, \overline{L_{\mathrm{x}}}$, and $N O$ were calculated after comparison with values obtained from 1000 random matrices, created based on the 'null model 2', where each simulated network is the same size of each empirical network and the probability of an interaction between one animal species and one plant species is proportional to the total number of interactions (Bascompte et al., 2003).

A Multiple Correspondence Analysis (MCA) was performed to identify patterns in the plant trait data for each of the three study cases. Prior to the MCA, we performed an imputation analysis to handle missing values (Josse and Husson, 2012) in the matrices of plant traits, since we were not able to find information in the literature for all traits concerning all plant species included in capuchin monkeys and coatis' diets. We did not include in the MCA those plant species with more than four traits with missing values. This method fills in missing values with plausible values using regularized iterative MCA algorithms in order to have a complete dataset that can be statistically analysed (Josse and Husson, 2012).

All statistical analyses, except $M_{\mathrm{B}}$, were carried out in the statistical computing environment $R$ 3.1.2 (R Core Team, 2014) using packages $R$ commander 2.0-0 (Fox, 2005) for diet indices and t-tests, bipartite 2.02 (Dormann, 2011; Dormann et al., 2009, 2008) for food web and graph analysis, missMDA 1.7.2 (Josse and Husson, 2012) and FactoMineR 1.27 (Husson et al., 2014; Lê et al., 2008) for imputation and MCA. $M_{\mathrm{B}}$ and its statistical significance were calculated using the software MODULAR 0.21 (Marquitti et al., 2014).

\section{Results}

\subsection{Overall diet}

Data on the diet of wild capuchin monkeys, genera Cebus and Sapajus, were obtained from 35 studies: 29 peer-reviewed articles, three book chapters, one dissertation, one thesis, and one unpublished dataset. They included three Cebus (C. albifrons [Humboldt, 1812], C. capucinus, and C. olivaceus Schomburgk, 1848) and six Sapajus species (S. apella [Linnaeus, 1758], S. cay [Illiger, 1815], S. libidinosus [Spix, 1823], S. macrocephalus [Spix, 1823], S. nigritus, and S. xanthosternos [Wied-Neuwied, 1826]). There were 1480 records of fruit consumption by these species involving 940 plant species. We found seven additional references related to occasional records of fruit consumption. Twelve out of 35 diet studies (one of which had information about two groups located in two different study sites) were conducted for $\geq 12$ months and had the relative frequency of occurrence of the different items in capuchins' diet reported or with enough information to be calculated (Appendix A).

Data on the diet of wild coatis ( $N$. narica and $N$. nasua) were obtained from 16 studies: 10 peer-reviewed articles, one book chapter, one dissertation, three theses and one unpublished dataset. There were 414 records of fruit consumption by these species, involving 272 plant species. We found seventeen additional references related to occasional records of fruit consumption. Ten out 16 diet studies were conducted for $\geq 12$ months and had the relative frequency of occurrence of the different items in coatis' diet reported or with enough information to be calculated (Appendix A).

Fruits plus seeds and animal matter (comprised mainly of invertebrates) were the main food categories eaten by both capuchins and coatis (Table 1; Appendix A). More infrequent food categories included non-fruit plant parts, such as leaves or roots, as well as crops/human waste.

Average trophic diversity $\left(H^{\prime}\right)$ and niche breadth $(B)$ for capuchins were 1.14 (SD 0.25) and 2.78 (SD 0.86), respectively. The same indexes
Table 1

Dietary composition in capuchin monkeys and coatis in the neotropical region. Values correspond to median percentages (interquartile ranges).

\begin{tabular}{lll}
\hline & capuchins & coatis \\
\hline $\boldsymbol{N}^{\mathrm{a}}$ & 12 & 10 \\
Fruits and seeds & $47(27)$ & $49(37)$ \\
Non-fruit plant parts & $16(21)$ & $2(6)$ \\
Animal matter & $27(17)$ & $48(25)$ \\
\hline
\end{tabular}

${ }^{\mathrm{a}}$ Number of reviewed studies (see Appendix A).

for coatis were 1.07 (SD 0.15) and 2.52 (SD 0.37), respectively. The two mammal groups did not differ significantly in $H^{\prime}(t=0.752$; $\mathrm{df}=18.4$; $P=0.462)$ or $B(t=0.965 ; \mathrm{df}=15.4 ; P=0.349)$ (Fig. 1$)$.

Considering the geographical distribution of both groups, we found studies reporting the diet composition of capuchin monkeys in four different geographical regions: Amazonia ( $\mathrm{n}=2$ studies), Coastal Atlantic Forest $(n=1)$, Interior Atlantic Forest $(n=8)$, and Pantanal $(\mathrm{n}=1)$. Coatis were studied on their diet compositions in only two geographical regions: Interior Atlantic Forest ( $\mathrm{n}=8$ studies), and Mesoamerica $(n=2)$ (Appendix A).

\subsection{Case studies}

The three focal communities showed differences in their network structures (Table 2; and see Fig. 2). At Fenix, a much higher percentage of fruiting species was shared by the two mammal taxa (57\%) compared to Godoy $(20 \%)$ and BCI (16\%). The number of links also differed considerably among communities (Table 2).

Connectance, mean number of links per species and niche overlap were all statistically significant when compared with null models for the three networks. Fenix network showed higher number of links, connectance values, and niche overlap between capuchins and coatis (Table 2). The normalised degree for capuchins did not vary greatly in the three networks but the same index for coatis had a greater variation among Fenix and the other networks (Table 2). None of the networks were significantly modular (Table 2 ).

\subsection{Plant traits}

We recorded a wide diversity of plant traits in the three studied communities (Fig. 2). Both mammal groups included in their diets fruits from each category of traits.

The results of the MCA did not reveal any combination of traits that might be influencing fruit choice by capuchins or coatis in our three focal communities. The dimensions for each of the three sites explained very little about the distribution of the categories of traits and the plant species were not grouped according to their consumers in the graphs (Fig. 3). This indicates an opportunistic and generalist diet for both groups.

\section{Discussion}

Fruits comprised the major part of the diet of both capuchins and coatis throughout the Neotropical region. Both groups presented similar values for niche breadth and trophic diversity, meaning that the average variety of foods they ate in different sites was similar, although animal matter was more frequently recorded for coatis. Coatis ingested a smaller number of fruit species compared to capuchins in all three case studies, but numbers increased with sampling effort, suggesting that long term studies are necessary to get a comprehensive picture of the diets of these mammals. Accordingly, the communities taken as case studies differed in the number of shared plant species by coatis and capuchins, but diet overlap was higher for the system sampled for a longer period (Fenix). A novel approach using a MCA to evaluate plant 
a)

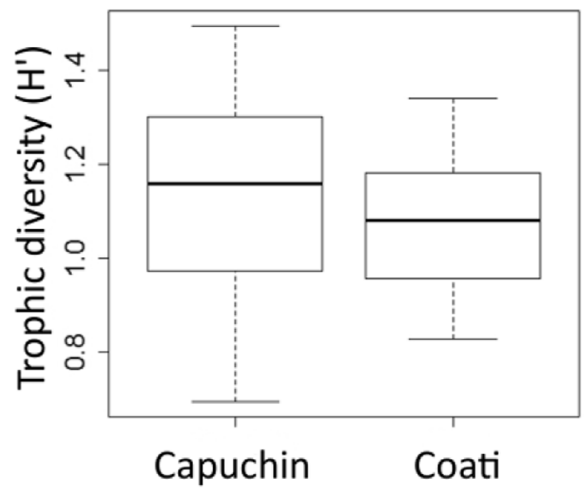

b)

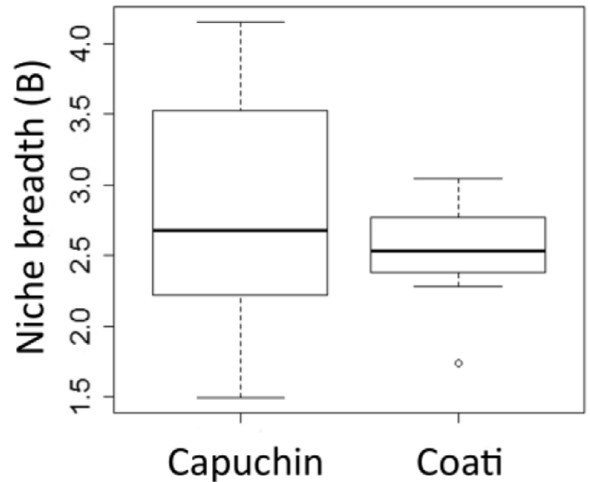

Fig. 1. Comparisons of the mean values ( \pm SE) of trophic diversity (a) and niche breadth (b) for capuchin monkeys and coatis.

Table 2

Network metrics $\left(S=\right.$ size; $\overline{L_{\mathrm{x}}}=$ mean number of links per species; $C=$ connectance; $N O=$ niche overlap; $N D_{c a}=$ mean normalised degree for capuchins; $N D_{c o}=$ mean normalised degree for coatis; and $M_{\mathrm{B}}=$ modularity) for three fruit-frugivore neotropical communities.

\begin{tabular}{llllllll}
\hline & $S$ & $L_{\mathrm{x}}$ & $C$ & $N O$ & $N D_{\text {ca }}$ & $N D_{\text {co }}$ & $M_{\mathrm{B}}$ \\
\hline Fenix & 103 & 1.54 & 0.79 & 0.73 & 0.90 & 0.34 & $0.18^{\mathrm{Ns}}$ \\
Godoy & 52 & 1.15 & 0.60 & 0.33 & 0.86 & 0.36 & $0.31^{\mathrm{NS}}$ \\
BCI & 110 & 1.14 & 0.58 & 0.27 & 0.79 & 0.67 & $0.34^{\mathrm{NS}}$ \\
\hline
\end{tabular}

NS stands for statistically non-significant metrics.

ecological and morphological traits on fruit choice by capuchins and coatis failed to detect any trait or trait combination that could be directly related to food choice.

The large representation of fruits plus seeds and animal matter (mostly insects) in both capuchin and coati diets indicates a very flexible diet, which is known to be affected by seasonal availability of food types (Alves-Costa et al., 2004; Hirsch, 2009; Mikich and Liebsch, 2014; Peres, 1994), cultivated crops (Beisiegel and Mantovani, 2006; Freitas et al., 2008; Galetti and Pedroni, 1994; Ludwig et al., 2005; Mikich, 2001; Pérez and Pacheco, 2006), and other anthropogenic disturbances (Aguiar et al., 2011; Ferreira et al., 2013; Sabbatini et al., 2008). This flexibility in diet is a possible explanation for the variation in feeding composition observed across the studies for each group.

Animal matter, especially arthropods, represented an important food source for coatis, being often chosen over fruits, although it may be more related to resource availability than to any feeding preference (Alves-Costa et al., 2004; Hirsch, 2009). Capuchins, on the other hand, consumed more non-fruit plant parts-as flowers, leaves and roots-than did the coatis. These monkeys have the ability to explore a wider range of different food items because of their manipulative skills and tool use (Boinski et al., 2000; Fragaszy et al., 1990; Mannu and Ottoni, 2009; Ottoni and Izar, 2008). Despite marked morphological and behavioural differences between the capuchins and coatis, they showed, on average, similar patterns of trophic diversity and niche breadth, confirming the overall generalist nature of their diets (Freese and Oppenheimer, 1981; Gompper, 1995; Gompper and Decker, 1998).

To date, there are few network studies documenting interactions between fruiting plants and generalist fruit-eating mammals (Bufalo et al., 2016; Hawes et al., 2013; Pires et al., 2014; Stevenson et al., 2015; Vidal et al., 2013). The three networks analysed had higher connectance values when compared with other fruit-frugivore networks such as bat- or bird-fruit networks with mean $C$ values of 0.30 and 0.22 , respectively (Mello et al., 2011). In fact, previous analyses of food webs found that small webs dominated by generalist omnivores tended to be those with higher connectance values (Dunne et al., 2002), as in our study. Niche overlap between the diets of coatis and capuchins regarding fruit species composition was particularly low in BCI and Godoy. Thus, the proportion of fruit species shared by the two taxa differed among the three communities, but in general most species were consumed by only one mammalian species. However, as already stated, sampling effort, especially study duration in years, may be affecting the results.

Since capuchins and coatis have been shown to disperse the seeds of most fruit species they eat (Alves-Costa and Eterovick, 2007; Mikich et al., 2015; Valenta and Fedigan, 2008; Wehncke and Domínguez, 2007), these two groups are likely to be important seed dispersers in disturbed habitats. Considering the differences observed in their diets and reported differences in movement patterns (Hirsch et al., 2013), they should have complementary roles in seed dispersal at the study sites (Schleuning et al., 2015). The normalised degree index indicates the generalisation of species (Martín González et al., 2010). In all three areas capuchins achieved high normalised degree values and included a wide range of fruit species in their diets, so the vast majority of fruit species available (considering what was eaten by both capuchins and coatis in the same community) were eaten by these primates. In turn, coatis showed high variation across communities in the quantity of fruit species eaten, in relation to the number of species available (also considering the total amount of species eaten by both taxa), which was highlighted by the contrasting values of normalised degree observed. Our results indicate that coatis are very flexible regarding the fruits included in their diet suggesting that fruit choice is related to availability.

Plant traits of the species eaten by capuchins and coatis at Fenix, Godoy and BCI were variable, including different plant abundances, life forms, number of seeds per fruit, seed sizes, and fruit types, colours and sizes. We did not detect any trait or trait combination closely linked to fruit choice by either coatis or capuchins. Due to their low dietary specialization and relatively large size, capuchins and coatis appear to use a broad variety of fruit. In tropical ecosystems, frugivores have been found to have generalized roles in networks because they require a high diversity of fruit plants (Dalsgaard et al., 2017). This contrasts with more specialized temperate fruit-frugivore systems, such as plant-bird networks, where particular fruit traits (e.g. fruit size) can constrain fruit choice, simply due to beak size determining the size of seed that can be consumed (Dehling et al., 2014). Future studies should focus on comparing mammals with contrasting levels of frugivory and diet specialization, in order to evaluate the effect of plant and fruit traits on diet composition and, consequently, on the structure of the community.

Whilst we did not find any diet restrictions caused by plant traits, capuchins and coatis have different life histories, which in turn influences their nutritional demands and diet compositions (Hirsch, 2009; Janson et al., 2012). Additionally, differences in terms of movement patterns and foraging patterns (Hirsch et al., 2013) may help to explain the differences observed in their frugivorous diets. Coatis are scansorial, 
a)

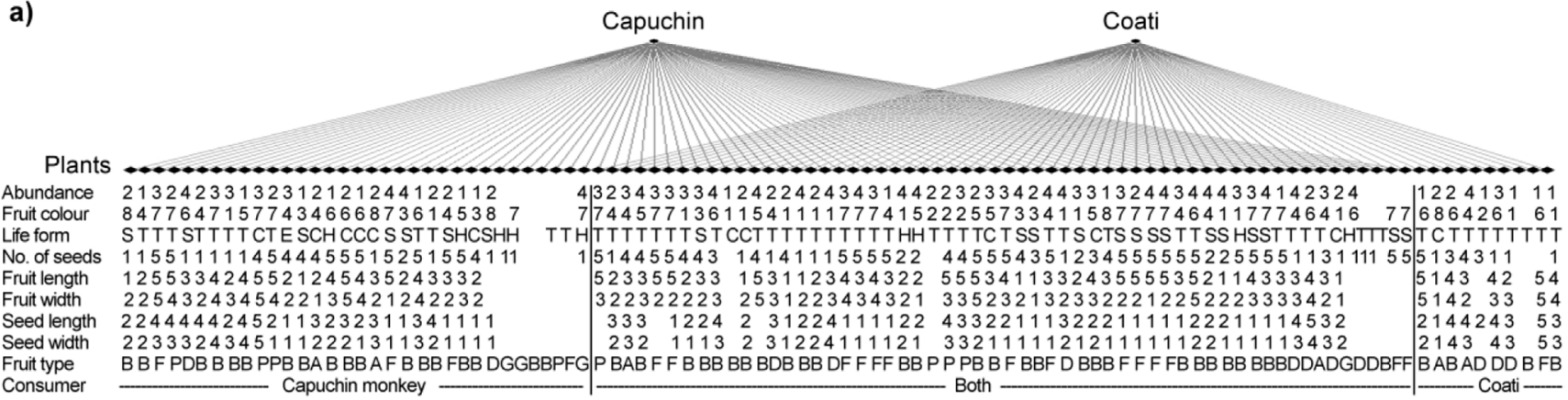

b)

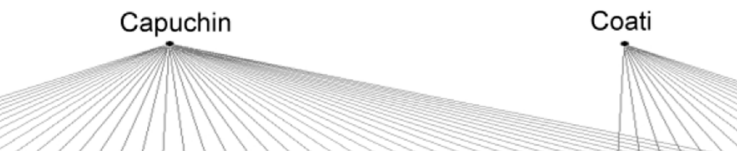

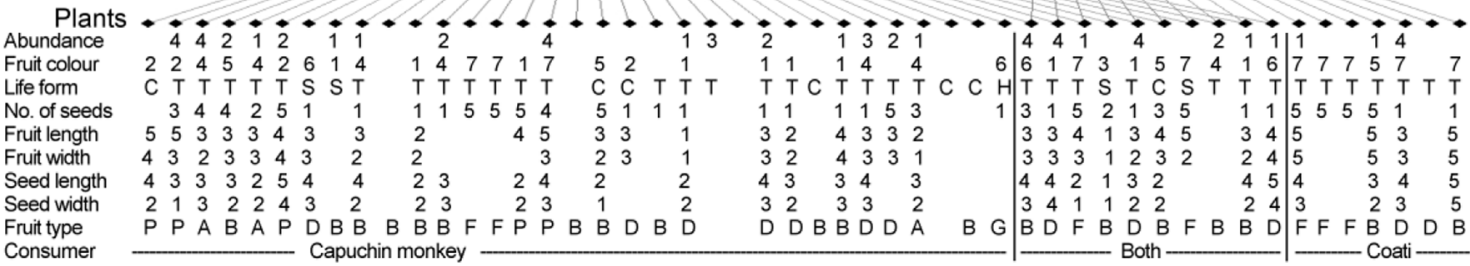

c) Capuchins

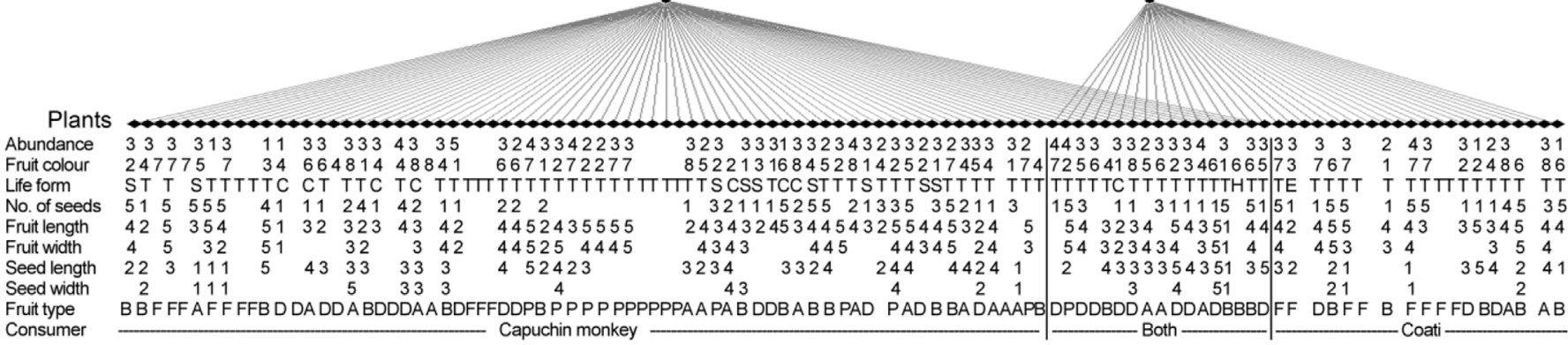

Fig. 2. Interactions among fruit plants and two generalist mammals in three focal communities: Fenix (a); Godoy (b); and BCI (c). The diversity of plant and fruit traits is listed below the lower vertices (plants) in each community. Legend for plant and fruit traits - plant abundance: $1=$ rare, $2=$ intermediate, $3=$ common, $4=$ abundant; fruit colour: $1=$ black, $2=$ brown, $3=$ blue/purple, $4=$ red/burgundy, $5=$ orange, $6=$ yellow, $7=$ green, $8=$ white; life form: $\mathrm{E}=$ epiphyte, $\mathrm{H}=$ herb, $\mathrm{C}=$ climber, $\mathrm{S}=$ shrub, $\mathrm{T}=$ tree; number of seeds per fruit (no. of seeds): $1=1$ seed, $2=2$ seeds; $3=3$ to 4 seeds, $4=5$ to 10 seeds, $5=>10$ seeds; fruit sizes: $1=[0,6] \mathrm{mm}, 2=] 6,10] \mathrm{mm}, 3=] 10,20] \mathrm{mm}, 4=] 20,50] \mathrm{mm}, 5=$ ] $50, \infty[\mathrm{mm}$; seed sizes: $1=[0,3] \mathrm{mm}, 2=] 3,6] \mathrm{mm}, 3=] 6,10] \mathrm{mm}, 4=] 10,20] \mathrm{mm}, 5=] 20, \infty[\mathrm{mm}$.

but they forage primarily on the ground where they eat fallen fruits among other items (Hirsch et al., 2013; Russell, 1983), while capuchins are primarily arboreal and feed in the forest canopy (Hirsch et al., 2013). Capuchins also have handling skills and tool use ability, which allows them to exploit a large range of fruits and seeds (Boinski et al., 2000).

Habitat loss and fragmentation can directly affect mammalian assemblages in disturbed habitats, particularly for frugivores (Chiarello, 1999). Coatis and capuchins can persist in relatively small and disturbed habitats, and even benefit from anthropogenic disturbances, persisting in sites where other mid-sized and large mammals cannot (Alves-Costa and Eterovick, 2007; Chiarello, 1999). Although there is some level of redundancy in seed dispersal by coatis and capuchins with other medium-sized mammals and large birds (Alves-Costa and Eterovick, 2007; Mikich, 2001), there still are a considerable proportion of fruit species that rely on these animals for seed dispersal. Therefore, these two groups are likely to perform key roles in forest maintenance and restoration through seed dispersal in such habitats. Our study was unfortunately unable to directly assess the level of seed dispersal caused by capuchins and coatis, however, since capuchins and coatis can disperse the seeds of most fruit species they eat (Alves-Costa and Eterovick, 2007; Mikich et al., 2015; Valenta and Fedigan, 2008;
Wehncke and Domínguez, 2007), we can infer that seed dispersal is likely to be highly correlated with fruit consumption.

Our study is an important initial attempt to investigate the interactions between capuchins, coatis, and the fruit species they eat and disperse, using a network and trait based approach. These taxa alone do not reflect the entirety of mutualistic interactions occurring in an intact forest where a large assemblage of frugivores may share and compete for the same resources. Nevertheless, taking into account the ongoing fragmentation and habitat loss throughout the Neotropical region (Dirzo and Raven, 2003; Laurance, 2007; Myers et al., 2000; Silva and Tabarelli, 2000), and their complementary seed dispersal services in disturbed habitats, capuchins and coatis are likely to play an essential role in Neotropical forest maintenance and recovery.

\section{Author contributions}

All authors conceived and designed the research; AA conducted the data collection; AA and RJM performed the analyzes; all authors discussed the results; AA wrote the manuscript; and RJM, SBM and OTL edited the manuscript. 
a)

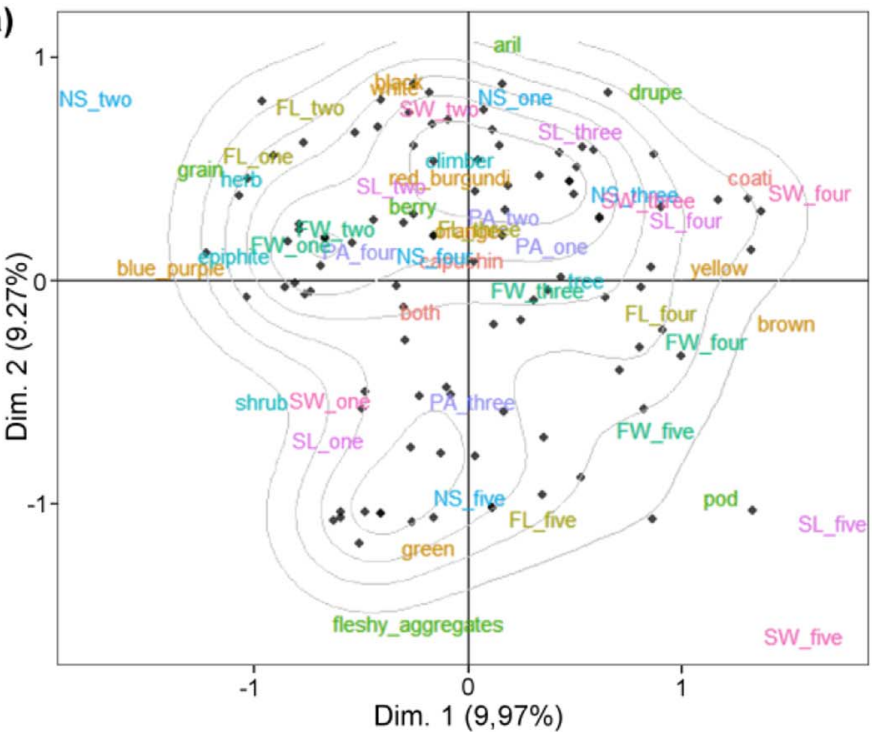

c)

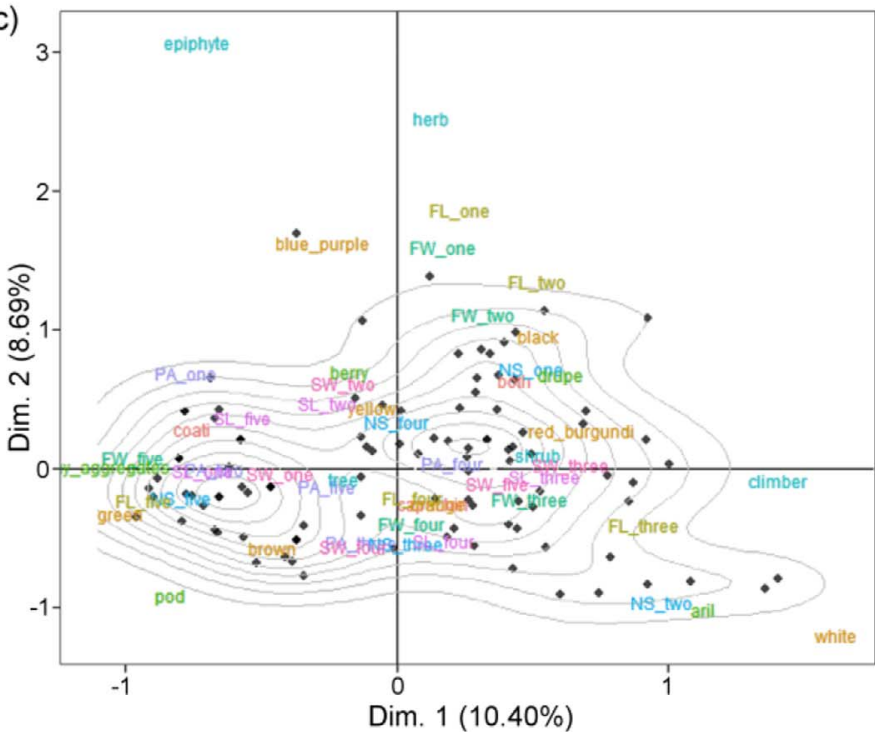

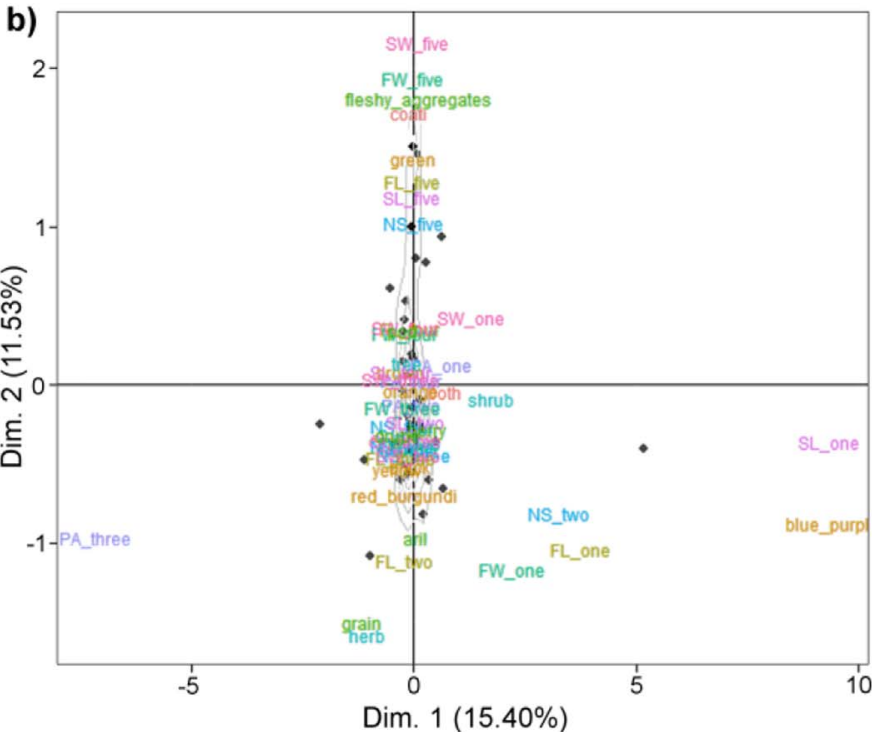

Variables

a Consumer

a Fruit colour (FC)

a Fruit length $(F L)$

a Fruit type (FT)

a Fruit width (FW)

a Plant life form (LF)

a Number of seeds per fruit (NS)

a Plant abundance (PA)

a Seed length (SL)

a Seed width (SW)

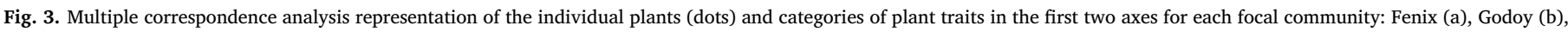
and BCI (c).

\section{Acknowledgments}

We are grateful to Ana C. Franken and Juliana B. Ruim, for their assistance in literature review, and to S. Joseph Wright, for providing plant trait data from BCI. Financial support was provided by EMBRAPA through a post-doctoral scholarship to S. B. Mikich and by CAPES Foundation through both a PDSE scholarship (Process no. 99999.012756/2013-00) and a doctorate scholarship to A. de Almeida.

\section{Appendix A}

Relative frequency of occurrence of food items in the diets of capuchin monkeys (genera Cebus and Sapajus) and coatis (genus Nasua) in the neotropical region.

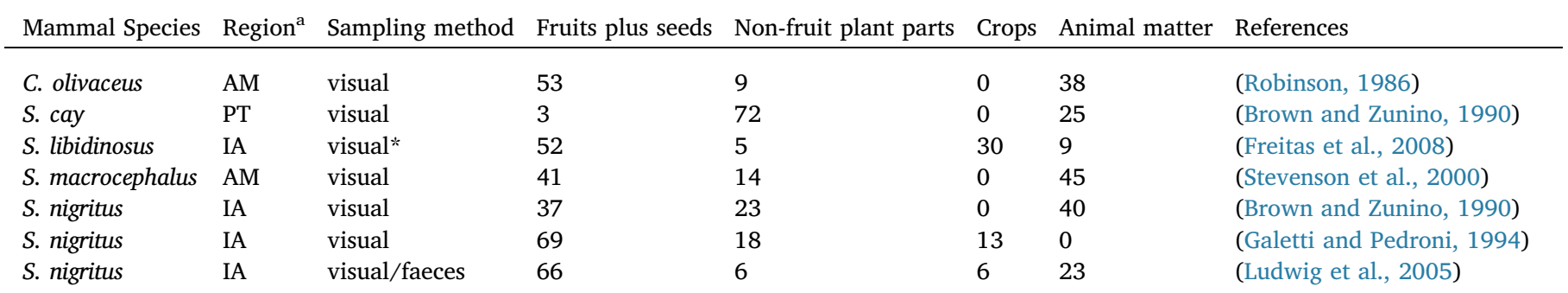




\begin{tabular}{|c|c|c|c|c|c|c|c|}
\hline S. nigritus & IA & faeces & 18 & 40 & 12 & 30 & $* *$ \\
\hline S. nigritus & IA & visual/faeces & 89 & 8 & 1 & 2 & (Rocha, 2001) \\
\hline N. narica & ME & visual & 60 & 0 & 0 & 40 & (Gompper, 1996) \\
\hline N. narica & ME & faeces & 46 & 0 & 0 & 54 & (Valenzuela, 1998) \\
\hline N. nasua & IA & stomach content & 20 & 7 & 0 & 73 & (Aguiar et al., 2011) \\
\hline N. nasua & IA & faeces & 11 & 9 & 21 & 59 & (Ferreira et al., 2013) \\
\hline N. nasua & IA & visual & 52 & 0 & 5 & 43 & (Hirsch, 2009) \\
\hline N. nasua & IA & faeces & 66 & 5 & 3 & 26 & (Mikich, 2001) \\
\hline N. nasua & IA & visual/faeces & 63 & 4 & 0 & 34 & (Rocha, 2001) \\
\hline N. nasua & IA & faeces & 9 & 0 & 5 & 86 & (Rocha-Mendes et al., 2010) \\
\hline
\end{tabular}

a AM: Amazonia; CA: Coastal Atlantic; IA: Interior Atlantic; ME: Mesoamerica; PT: Pantanal.

*In this case $4 \%$ of food items were not identified. **S.B. Mikich et al., unpublished

\section{References}

Aguiar, L.M., Moro-Rios, R.F., Silvestre, T., Silva-Pereira, J.E., Bilski, D.R., Passos, F.C., Sekiama, M.L., Rocha, V.J., 2011. Diet of brown-nosed coatis and crab-eating raccoons from a mosaic landscape with exotic plantations in southern Brazil. Stud. Neotrop. Fauna Environ. 46, 153-161. http://dx.doi.org/10.1080/01650521.2011. 640567.

Alfaro, J.W.L., Boubli, J.P., Olson, L.E., Di Fiore, A., Wilson, B., Gutiérrez-Espeleta, G.A., Chiou, K.L., Schulte, M., Neitzel, S., Ross, V., Schwochow, D., Nguyen, M.T.T., Farias, I., Janson, C.H., Alfaro, M.E., 2012a. Explosive Pleistocene range expansion leads to widespread Amazonian sympatry between robust and gracile capuchin monkeys. J. Biogeogr. 39, 272-288. http://dx.doi.org/10.1111/j.1365-2699.2011.02609.x.

Alfaro, J.W.L., Silva, J. de E.S.E.S.E., Rylands, A.B., 2012b. How different are robust and gracile capuchin monkeys? An argument for the use of Sapajus and Cebus. Am. J. Primatol. 74, 273-286. http://dx.doi.org/10.1002/ajp.22007.

Alves-Costa, C.P., Eterovick, P.C., 2007. Seed dispersal services by coatis (Nasua nasua, Procyonidae) and their redundancy with other frugivores in southeastern Brazil. Acta Oecol. 32, 77-92. http://dx.doi.org/10.1016/j.actao.2007.03.001.

Alves-Costa, C.P., Fonseca, G.A.B. Da, Christófaro, C., 2004. Variation in the diet of the brown-nosed coati (Nasua nasua) in southeastern Brazil. J. Mammal. 85, 478-482. http://dx.doi.org/10.1644/1545-1542(2004)085<0478:VITDOT > 2.0.CO;2.

Amaral, C., 2007. Dieta de duas espécies carnívoras simpátricas graxaim-do-mato Cerdocyon thous (Linnaeus, 1766) e quati Nasua nasua (Linnaeus, 1766) nos municipios de Tijucas do Sul e Agudos do Sul, estado do Parana. Universidade Federal do Paraná.

Barber, M.J., 2007. Modularity and community detection in bipartite networks. Phys. Rev. E 76, 1-11. http://dx.doi.org/10.1103/PhysRevE.76.066102.

Bascompte, J., Jordano, P., 2007. Plant-animal mutualistic networks: the architecture of biodiversity. Annu. Rev. Ecol. Evol. Syst. 38, 567-593. http://dx.doi.org/10.1146/ annurev.ecolsys.38.091206.095818.

Bascompte, J., Jordano, P., Melián, C.J., Olesen, J.M., 2003. The nested assembly of plant-animal mutualistic networks. Proc. Natl. Acad. Sci. Unit. States Am. 100, 9383-9387. http://dx.doi.org/10.1073/pnas.1633576100.

Beisiegel, B.M., Mantovani, W., 2006. Habitat use, home range and foraging preferences of the coati Nasua nasua in a pluvial tropical Atlantic forest area. J. Zool. 269, 77-87. http://dx.doi.org/10.1111/j.1469-7998.2006.00083.x.

Bianchi, R. de C., Campos, R.C., Xavier-Filho, N.L., Olifiers, N., Gompper, M.E., Mourão, G., 2014. Intraspecific, interspecific, and seasonal differences in the diet of three midsized carnivores in a large neotropical wetland. Acta Theriol. 59, 13-23. http://dx. doi.org/10.1007/s13364-013-0137-x.

Boinski, S., Quatrone, R.P., Swartz, H., 2000. Substrate and tool use by brown capuchins in Suriname: ecological contexts and cognitive bases. Am. Anthropol. 102, 741-761.

Brown, A.D., Zunino, G.E., 1990. Dietary variability in Cebus apella in extreme habitats: evidence for adaptability. Folia Primatol. 54, 187-195. http://dx.doi.org/10.1159/ 000156443.

Bufalo, F.S., Galetti, M., Culot, L., 2016. Seed dispersal by primates and implications for the conservation of a biodiversity hotspot, the Atlantic Forest of South America. Int. J. Primatol. 37, 333-349. http://dx.doi.org/10.1007/s10764-016-9903-3.

Canale, G.R., Bernardo, C.S.S., 2016. Predator-prey interaction between two threatened species in a Brazilian hotspot. Biota Neotropica 16http://dx.doi.org/10.1590/1676 0611-BN-2015-0059. e0059.

Chiarello, A.G., 1999. Effects of fragmentation of the Atlantic forest on mammal communities in south-eastern Brazil. Biol. Conserv. 89, 71-82.

Croat, T.B., 1978. Flora of Barro Colorado Island. Stanford University Press, Stanford.

Cullen Jr., L., Bodmer, R.E., Pádua, C.V., 2000. Effects of hunting in habitat fragments of the Atlantic forests. Brazil. Biol. Conserv 95, 49-56. http://dx.doi.org/10.1016/ S0006-3207(00)00011-2

Dalsgaard, B., Schleuning, M., Maruyama, P.K., Dehling, D.M., Sonne, J., VizentinBugoni, J., Zanata, T.B., Fjeldså, J., Böhning-Gaese, K., Rahbek, C., 2017. Opposed latitudinal patterns of network-derived and dietary specialization in avian plantfrugivore interaction systems. Ecography. http://dx.doi.org/10.1111/ecog.02604.

Dehling, D.M., Töpfer, T., Schaefer, H.M., Jordano, P., Böhning-Gaese, K., Schleuning, M., 2014. Functional relationships beyond species richness patterns: trait matching in plant-bird mutualisms across scales. Global Ecol. Biogeogr. 23, 1085-1093. http:// dx.doi.org/10.1111/geb.12193.

Dirzo, R., Raven, P.H., 2003. Global state of biodiversity and loss. Annu. Rev. Environ. Resour. 28, 137-167. http://dx.doi.org/10.1146/annurev.energy.28.050302. 105532.

Donatti, C.I., Guimarães, P.R., Galetti, M., Pizo, M.A., Marquitti, F.M.D., Dirzo, R., 2011. Analysis of a hyper-diverse seed dispersal network: modularity and underlying mechanisms. Ecol. Lett. 14, 773-781. http://dx.doi.org/10.1111/j.1461-0248.2011. 01639.x.

Dormann, C.F., 2011. How to be a specialist? Quantifying specialisation in pollination networks. Netw. Biol. 1, 1-20.

Dormann, C.F., Fründ, J., Blüthgen, N., Gruber, B., 2009. Indices, graphs and null models: analyzing bipartite ecological networks. Open Ecol. J. 2, 7-24.

Dormann, C.F., Gruber, B., Fründ, J., 2008. Introducing the bipartite package: analysing ecological networks. R. News 8, 8-11.

Duncan, R.S., Chapman, C.A., 2002. Limitations of animal seed dispersal for enhancing forest succession on degraded lands. In: Levey, D.J., Silva, W.R., Galetti, M. (Eds.), Seed Dispersal and Frugivory: Ecology, Evolution and Conservation. CABI Publishing, Wallingford, pp. 437-450.

Dunne, J.A., Williams, R.J., Martinez, N.D., 2002. Food-web structure and network theory: the role of connectance and size. Proc. Natl. Acad. Sci. U. S. A 99, 12917-12922. http://dx.doi.org/10.1073/pnas.192407699.

Eisenberg, J.F., Thorington Jr., R.W., 1973. A preliminary analysis of a neotropical mammal fauna. Biotropica 5, 150-161.

Ferreira, G.A., Nakano-Oliveira, E., Genaro, G., Lacerda-Chaves, A.K., 2013. Diet of the coati Nasua nasua (Carnivora: Procyonidae) in an area of woodland inserted in an urban environment in Brazil. Rev. Chil. Hist. Nat. 86, 95-102.

Fox, J., 2005. The R commander: a basic statistics graphical user interface to R. J. Stat. Software 14, 1-42.

Fragaszy, D.M., Visalberghi, E., Robinson, J.G., 1990. Variability and adaptability in the genus Cebus. Folia Primatol. 54, 114-118.

Freese, C.H., Oppenheimer, J.R., 1981. The capuchin monkeys, genus Cebus. In: CoimbraFilho, A.F., Mittermeier, R.M.M. (Eds.), Ecology and Behavior of Neotropical Primates. Academia Brasileira de Ciências, Rio de Janeiro, pp. 331-390.

Freitas, C.H. De, Setz, E.Z.F., Araújo, A.R.B., Gobbi, N., 2008. Agricultural crops in the diet of bearded capuchin monkeys, Cebus libidinosus Spix (Primates: Cebidae). in forest fragments in southeast Brazil. Rev. Bras. Zool 25, 32-39. http://dx.doi.org/10 1590/S0101-81752008000100006.

Galetti, M., Dirzo, R., 2013. Ecological and evolutionary consequences of living in a defaunated world. Biol. Conserv. 163, 1-6. http://dx.doi.org/10.1016/j.biocon.2013. 04.020.

Galetti, M., Guevara, R., Cortes, M.C., Fadini, R., Von Matter, S., Leite, A.B., Labecca, F., Ribeiro, T., Carvalho, C.S., Collevatti, R.G., Pires, M.M., Guimaraes, P.R., Brancalion, P.H., Ribeiro, M.C., Jordano, P., 2013. Functional extinction of birds drives rapid evolutionary changes in seed size. Science 340 (80), 1086-1090. http://dx.doi.org/ 10.1126/science.1233774.

Galetti, M., Pedroni, F., 1994. Seasonal diet of capuchin monkeys (Cebus apella) in a semideciduous forest in south-east Brazil. J. Trop. Ecol. 10, 27-39.

Gautier-Hion, A., Duplantier, J.-M., Quris, R., Feer, F., Sourd, C., Decoux, J.-P., Dubost, G., Emmons, L., Erard, C., Hecketsweiler, P., Moungazi, A., Roussilhon, C., Thiollay, J.-M., 1985. Fruit characters as a basis of fruit choice and seed dispersal in a tropical forest vertebrate community. Oecologia 65, 324-337.

Gompper, M.E., 1996. Sociality and asociality in white-nosed coatis (Nasua narica): foraging costs and benefits. Behav. Ecol. 7, 254-263. http://dx.doi.org/10.1093/ beheco/7.3.254.

Gompper, M.E., 1995. Nasua narica. Mamm. Species 487, 1-10. 
Gompper, M.E., Decker, D.M., 1998. Nasua nasua. Mamm. Species 580, 1-9.

Gonzalez-Castro, A., Yang, S., Nogales, M., Carlo, T.A., 2015. Relative importance of phenotypic trait matching and species' abundances in determining plant-avian seed dispersal interactions in a small insular community. AoB Plants 7http://dx.doi.org/ 10.1093/aobpla/plv017. plv017.

Hawes, J.E., Calouro, A.M., Peres, C.A., 2013. Sampling effort in neotropical primate diet studies: collective gains and underlying geographic and taxonomic biases. Int. J. Primatol. 34, 1081-1104. http://dx.doi.org/10.1007/s10764-013-9738-0.

Hirsch, B.T., 2009. Seasonal variation in the diet of ring-tailed coatis (Nasua nasua) in Iguazu, Argentina. J. Mammal. 90, 136-143. http://dx.doi.org/10.1644/08-MAMMA-050.1.

Hirsch, B.T., Tujague, M.P., Di Blanco, Y.E., Di Bitetti, M.S., Janson, C.H., 2013. Comparing capuchins and coatis: causes and consequences of differing movement ecology in two sympatric mammals. Anim. Behav. 86, 331-338. http://dx.doi.org/ 10.1016/j.anbehav.2013.05.023.

Hladik, A., Hladik, C.M., 1969. Rapports trophiques entre végétation et Primates dans la forêt de Barro Colorado (Panama). Rev. d'Écologie (La Terre La Vie) 23, 25-117.

Howe, H.F., Miriti, M.N., 2004. When seed dispersal matters. Bioscience 54, 651-660. http://dx.doi.org/10.1641/0006-3568(2004)054[0651:wsdm]2.0.co;2.

Howe, H.F., Smallwood, J., 1982. Ecology of seed dispersal. Annu. Rev. Ecol. Evol. Syst. 13, 201-228. http://dx.doi.org/10.1146/annurev.es.13.110182.001221.

Husson, F., Josse, J., Lê, S., Mazet, J., 2014. FactoMineR: Multivariate Exploratory Data Analysis and Data Mining with R. R package version 1.27.

IUCN, 2016. The IUCN Red List of Threatened Species. Version 2016-1.

IUCN, 2013. The IUCN Red List of Threatened Species. Version 2013.2.

Janson, C.H., 1985. Aggressive competition and individual food consumption in wild brown capuchin monkeys (Cebus apella). Behav. Ecol. Sociobiol. 18, 125-138. http://dx.doi.org/10.1007/BF00299041.

Janson, C.H., Baldovino, M.C., Di Bitetti, M., 2012. The group life cycle and demography of Brown capuchin monkeys (Cebus [apella] nigritus) in Iguazú National Park, Argentina. In: Kappeler, P.M., Watts, D.P. (Eds.), Long-term Field Studies of Primates. Springer Berlin Heidelberg, Berlin, Heidelberg, pp. 185-212. http://dx.doi.org/10. 1007/978-3-642-22514-7 9.

Janzen, D.H., 1971. Seed predation by animals. Annu. Rev. Ecol. Evol. Syst. 2, 465-492. http://dx.doi.org/10.1146/annurev.es.02.110171.002341.

Jordano, P., 2000. Fruits and frugivory. In: Fenner, M. (Ed.), Seeds: the Ecology of Regeneration in Plant Communities. CABI Publishing, Wallingford, pp. 125-166.

Jordano, P., 1995. Angiosperm fleshy fruits and seed dispersers: a comparative analysis of adaptation and constraints in plant-animal interactions. Am. Nat. 145, 163-191. http://dx.doi.org/10.1086/285735.

Jordano, P., Bascompte, J., Olesen, J.M., 2003. Invariant properties in coevolutionary networks of plant-animal interactions. Ecol. Lett. 6, 69-81. http://dx.doi.org/10. 1046/j.1461-0248.2003.00403.x.

Jordano, P., Godoy, J.A., 2002. Frugivore-generated seed shadows: a landscape view of demographic and genetic effects. In: Levey, D.J., Silva, W.R., Galetti, M. (Eds.), Seed Dispersal and Frugivory: Ecology, Evolution and Conservation. CABI Publishing, Wallingford, pp. 305-321.

Josse, J., Husson, F., 2012. Handling missing values in exploratory multivariate data analysis methods. J. la Société Française Stat 153, 79-99.

Junker, R.R., Blüthgen, N., Brehm, T., Binkenstein, J., Paulus, J., Schaefer, H.M., Stang, M., 2013. Specialization on traits as basis for the niche-breadth of flower visitors and as structuring mechanism of ecological networks. Funct. Ecol. 27, 329-341. http:// dx.doi.org/10.1111/1365-2435.12005.

Kaufmann, J.H., 1962. Ecology and social behavior of the coati, Nasua narica, of Barro Colorado Island, Panama. Univ. Calif. Publ. Zool. 60, 95-222.

Kissling, W.D., Schleuning, M., 2015. Multispecies interactions across trophic levels at macroscales: retrospective and future directions. Ecography 38, 346-357. http://dx. doi.org/10.1111/ecog.00819.

Knight, D.H., 1975. A phytosociological analysis of species-rich tropical forest on Barro Colorado Island, Panama. Ecol. Monogr. 45, 259-284. http://dx.doi.org/10.2307/ 1942424.

Kottek, M., Grieser, J., Beck, C., Rudolf, B., Rubel, F., 2006. World map of the KöppenGeiger climate classification updated. Meteorol. Z. 15, 259-263. http://dx.doi.org/ 10.1127/0941-2948/2006/0130.

Laurance, W.F., 2007. Have we overstated the tropical biodiversity crisis? Trends Ecol. Evol. 22, 65-70. http://dx.doi.org/10.1016/j.tree.2006.09.014.

Lê, S., Josse, J., Husson, F., 2008. FactoMineR: an R package for multivariate analysis. J. Stat. Software 25, 1-18.

Ludwig, G., Aguiar, L.M., Rocha, V.J., 2005. Uma avaliação da dieta, da área de vida e das estimativas populacionais de Cebus nigritus (Goldfuss, 1809) em um fragmento florestal no norte do estado do Paraná. Neotrop. Primates 13, 12-18.

Maglianesi, M.A., Blüthgen, N., Böhning-Gaese, K., Schleuning, M., 2014. Morphological traits determine specialization and resource use in plant-hummingbird networks in the neotropics. Ecology 95, 3325-3334. http://dx.doi.org/10.1890/13-2261.1.sm.

Mannu, M., Ottoni, E.B., 2009. The enhanced tool-kit of two groups of wild bearded capuchin monkeys in the Caatinga: tool making, associative use, and secondary tools. Am. J. Primatol. 71, 242-251. http://dx.doi.org/10.1002/ajp.20642.

Marquitti, F.M.D., Guimarães Jr., P.R., Pires, M.M., Bittencourt, L.F., 2014. MODULAR software for the autonomous computation of modularity in large network sets. Ecography 37, 221-224. http://dx.doi.org/10.1111/j.1600-0587.2013.00506.x.

Martín González, A.M., Dalsgaard, B., Olesen, J.M., 2010. Centrality measures and the importance of generalist species in pollination networks. Ecol. Complex. 7, 36-43. http://dx.doi.org/10.1016/j.ecocom.2009.03.008.

Maruyama, P.K., Vizentin-Bugoni, J., Oliveira, G.M., Oliveira, P.E., Dalsgaard, B., 2014. Morphological and spatio-temporal mismatches shape a Neotropical savanna planthummingbird network. Biotropica 46, 740-747. http://dx.doi.org/10.1111/btp.
12170.

Mello, M.A.R., Marquitti, F.M.D., Guimarães, P.R., Kalko, E.K.V., Jordano, P., de Aguiar, M.A.M., 2011. The modularity of seed dispersal: differences in structure and robustness between bat- and bird-fruit networks. Oecologia 167, 131-140. http://dx. doi.org/10.1007/s00442-011-1984-2.

Mikich, S.B., 2001. Frugivoria e dispersão de sementes em uma pequena reserva isolada do Estado do Paraná. Universidade Federal do Paraná, Brasil.

Mikich, S.B., Liebsch, D., 2014. Damage to forest plantations by tufted capuchins (Sapajus nigritus): too many monkeys or not enough fruits? For. Ecol. Manage 314, 9-16. http://dx.doi.org/10.1016/j.foreco.2013.11.026.

Mikich, S.B., Liebsch, D., de Almeida, A., Miyazaki, R.D., 2015. O papel do macaco-prego Sapajus nigritus na dispersão de sementes e no controle potencial de insetos-praga em cultivos agrícolas e florestais. In: Parron, L.M., Garcia, J.R., Oliveira, E.B. de, Brown, G.G., Prado, R.B. (Eds.), Serviços Ambientais Em Sistemas Agrícolas E Florestais Do Bioma Mata Atlântica. Embrapa, Brasília, pp. 257-265.

Mikich, S.B., Oliveira, K.L. de, 2003. Revisão do plano de manejo do Parque Estadual Vila Rica do Espírito Santo, Fênix - PR. Mater Natura - Instituto de Estudos Ambientais/ Fundo Nacional do Meio Ambiente, Curitiba/PR.

Mikich, S.B., Silva, S.M., 2001. Composição florística e fenologia das espécies zoocóricas de remanescentes de floresta estacional semidecidual no centro-oeste do Paraná, Brasil. Acta Bot. Bras. 15, 89-113. https://doi.org/10.1590/S0102 33062001000100010.

Moscow, D., Vaughan, C., 1987. Troop movement and food habits of white-faced monkeys in a tropical-dry forest. Rev. Biol. Trop. 35, 287-297.

Myers, N., Mittermeier, R.A., Mittermeier, C.G., da Fonseca, G.A.B., Kent, J., 2000. Biodiversity hotspots for conservation priorities. Nature 403, 853-858. http://dx.doi. org $/ 10.1038 / 35002501$.

Odum, E.P., Barrett, G.W., 2008. Fundamentos de Ecologia, fifth ed. Cengage Learning, São Paulo.

Olesen, J.M., Bascompte, J., Dupont, Y.L., Jordano, P., 2007. The modularity of pollination networks. Proc. Natl. Acad. Sci. U. S. A 104, 19891-19896. http://dx.doi.org/ 10.1073/pnas.0706375104.

Ottoni, E.B., Izar, P., 2008. Capuchin monkey tool use: overview and implications. Evol Anthropol. 17, 171-178. http://dx.doi.org/10.1002/evan.20185.

Peres, C.A., 1994. Primate responses to phenological changes in an amazonian terra firme forest. Biotropica 26, 98. http://dx.doi.org/10.2307/2389114.

Peres, C.A., Palacios, E., 2007. Basin-wide effects of game harvest on vertebrate population densities in Amazonian forests: implications for animal-mediated seed dispersal. Biotropica 39, 304-315.

Peres, C.A., van Roosmalen, M., 2002. Primate frugivory in two species-rich neotropica forests: implications for the demography of large-seeded plants in overhunted areas. In: Levey, D.J., Silva, W.R., Galetti, M. (Eds.), Seed Dispersal and Frugivory: Ecology, Evolution and Conservation. CABI Publishing, Wallingford, pp. 407-421.

Pérez, E., Pacheco, L.F., 2006. Damage by large mammals to subsistence crops within a protected area in a montane forest of Bolivia. Crop Protect. 25, 933-939. http://dx. doi.org/10.1016/j.cropro.2005.12.005.

Pires, M.M., Galetti, M., Donatti, C.I., Pizo, M.A., Dirzo, R., Guimarães, P.R., 2014. Reconstructing past ecological networks: the reconfiguration of seed-dispersal in teractions after megafaunal extinction. Oecologia 175, 1247-1256. http://dx.doi. org/10.1007/s00442-014-2971-1.

R Core Team, 2014. R: a Language and Environment for Statistical Computing. Version 3.1.2.

Rímoli, J., Strier, K.B., Ferrari, S.F., 2008. Seasonal and longitudinal variation in the behavior of free-ranging black tufted capuchins Cebus nigritus (Goldfuss, 1809) in a fragment of Atlantic Forest in Southeastern Brazil. In: Ferrari, S.F., Rímoli, J. (Eds.), A Primatologia No Brasil. Sociedade Brasileira de Primatologia, Biologia Geral e Experimental - UFS, Aracaju, pp. 130-146.

Robinson, J.G., 1986. Seasonal variation in use of time and space by the wedge-capped capuchin monkey, Cebus olivaceus: implications for foraging theory. Smithsonian Contrib. Zool. 1-60. http://dx.doi.org/10.5479/si.00810282.431.

Rocha-Mendes, F., Mikich, S.B., Bianconi, G.V., Pedro, W.A., 2005. Mamíferos do município de Fênix, Paraná, Brasil: Etnozoologia e Conservação. Rev. Bras. Zool. 22, 991-1002. http://dx.doi.org/10.1590/S0101-81752005000400027.

Rocha-Mendes, F., Mikich, S.B., Quadros, J., Pedro, W.A., 2010. Feeding ecology of carnivores (Mammalia, Carnivora) in Atlantic forest remnants, southern Brazil. Biota Neotropica 10, 21-30.

Rocha, V.J., 2001. Ecologia de mamíferos de médio e grande portes do Parque Estadual Mata dos Godoy. Universidade Federal do Paraná, Londrina (PR).

Russell, J.K., 1983. Timing of reproduction by coatis (Nasua narica) in relation to fluctuations in food resources. In: Leigh Jr.E.G., Rand, A.S., Windsor, D.M. (Eds.), The Ecology of a Tropical Forest: Seasonal Rhythms and Long-term Changes. Oxford University Press, Oxford, pp. 413-431.

Sabbatini, G., Stammati, M., Tavares, M.C.H., Visalberghi, E., 2008. Behavioral flexibility of a group of bearded capuchin monkeys (Cebus libidinosus) in the National Park of Brasília (Brazil): consequences of cohabitation with visitors. Brazilian J. Biol. 68, 685-693.

Schleuning, M., Fründ, J., García, D., 2015. Predicting ecosystem functions from biodiversity and mutualistic networks: an extension of trait-based concepts to plant-anima interactions. Ecography 38, 380-392. http://dx.doi.org/10.1111/ecog.00983.

Silva, J.M.C. da, Tabarelli, M., 2000. Tree species impoverishment and the future flora of the Atlantic forest of northeast Brazil. Nature 404, 72-74. http://dx.doi.org/10. 1038/35003563.

Stevenson, P.R., Link, A., González-Caro, S., Torres-Jiménez, M.F., 2015. Frugivory in canopy plants in a western Amazonian forest: dispersal systems, phylogenetic ensembles and keystone plants. PLoS One 10, 1-23. http://dx.doi.org/10.1371/journal. pone.0140751. 
Stevenson, P.R., Quiñones, M.J., Ahumada, J.A., 2000. Influence of fruit availability on ecological overlap among four neotropical primates at Tinigua National Park, Colombia. Biotropica 32, 533-544. http://dx.doi.org/10.1646/0006-3606(2000) 032.

Terborgh, J., 1995. Wildlife in managed tropical forests: a Neotropical perspective. In: Lugo, A.E., Lowe, C. (Eds.), Tropical Forests: Management and Ecology, Ecological Studies. Springer New York, New York, NY, pp. 331-342. http://dx.doi.org/10.1007/ 978-1-4612-2498-3_13.

Valenta, K., Fedigan, L.M., 2008. How much is a lot? Seed dispersal by white-faced capuchins and implications for disperser-based studies of seed dispersal systems. Primates 49, 169-175. http://dx.doi.org/10.1007/s10329-008-0087-0.

Valenzuela, D., 1998. Natural history of the White-nosed Coati, Nasua narica, in a tropical dry forest of western Mexico. Rev. Mex. Mastozoología 3, 26-44.

Vázquez, D.P., Chacoff, N.P., Cagnolo, L., 2009. Evaluating multiple determinants of the structure of plant-animal mutualistic networks. Ecology 90, 2039-2046. http://dx. doi.org/10.1890/08-1837.1.

Vidal, M.M., Pires, M.M., Guimarães Jr., P.R., 2013. Large vertebrates as the missing components of seed-dispersal networks. Biol. Conserv. 163, 42-48. http://dx.doi.org/ 10.1016/j.biocon.2013.03.025.

Vizentin-Bugoni, J., Maruyama, P.K., Sazima, M., 2014. Processes entangling interactions in communities: forbidden links are more important than abundance in a hummingbird-plant network. Proc. R. Soc. B 281, 20132397. http://dx.doi.org/10 1098/rspb.2013.2397.

Wehncke, E.V., Domínguez, C.A., 2007. Seed dispersal ecology of non-restricted frugivores, capuchin monkeys in three neotropical forests. J. Trop. Ecol. 23, 519-528. http://dx.doi.org/10.1017/S0266467407004257.

Wright, S.J., Gompper, M.E., DeLeon, B., 1994. Are large predators keystone species in neotropical Forests? The evidence from Barro Colorado island. Oikos 71, 279-294. http://dx.doi.org/10.2307/3546277.

Wright, S.J., Kitajima, K., Kraft, N.J.B., Reich, P.B., Wright, I.J., Bunker, D.E., Condit, R., Dalling, J.W., Davies, S.J., Díaz, S., Engelbrecht, B.M.J., Harms, K.E., Hubbell, S.P., Marks, C.O., Ruiz-Jaen, M.C., Salvador, C.M., Zanne, A.E., 2010. Functional traits and the growth-mortality trade-off in tropical trees. Ecology 91, 3664-3674.

Wright, S.J., Stoner, K.E., Beckman, N., Corlett, R.T., Dirzo, R., Muller-Landau, H.C., Nuñez-Iturri, G., Peres, C.A., Wang, B.C., 2007. The plight of large animals in tropical forests and the consequences for plant regeneration. Biotropica 39, 289-291. http:// dx.doi.org/10.1111/j.1744-7429.2007.00293.x.

Zhou, Y.-B., Newman, C., Xu, W.-T., Buesching, C.D., Zalewski, A., Kaneko, Y., Macdonald, D.W., Xie, Z.-Q., 2011. Biogeographical variation in the diet of Holarctic martens (genus Martes, Mammalia: carnivora: Mustelidae): adaptive foraging in generalists. J. Biogeogr. 38, 137-147. http://dx.doi.org/10.1111/j.1365-2699.2010 02396.x. 